\title{
The used of chopped banana Musa paradisiaca stem for stimulating immune responses and streptococcosis resistance of Nile tilapia Oreochromis niloticus
}

\section{Cacahan batang pisang ambon Musa paradisiaca untuk meningkatkan respons imun dan daya tahan ikan nila Oreochromis niloticus terhadap streptococcosis}

\author{
Lilis Nurjanah*, Sri Nuryati, Alimuddin, Kukuh Nirmala \\ Department of Aquaculture, Faculty of Fisheries and Marine Sciences, Bogor Agricultural University, Bogor, \\ Indonesia \\ *E-mail: lilisnurjannah19@gmail.com, sri.nuryati606@gmail.com
}

(Received November 21, 2017; Accepted July 24, 2018)

\begin{abstract}
Streptococcosis is caused by S. agalactiae and often found in Nile tilapia farming. This study was performed to determine the effectiveness of the concentration and frequency of giving chopped banana stem as the immunostimulant to stimulate the non-specific immune system of tilapia against $S$. agalactiae. This study used factorial completely randomized design, consisted of two factors: concentration and changing frequency (replacement time interval) of banana stem on Nile tilapia rearing media with 11 treatments and three replications each treatment. The concentration of $5 \mathrm{~g} / \mathrm{L}, 10 \mathrm{~g} / \mathrm{L}$, and $15 \mathrm{~g} / \mathrm{L}$ and the three days, seven days and no replacement time interval were used in this study. The immersion treatment with the chopped banana stem was done for 14 days, then the challenge test with $S$. agalactiae was on the $15^{\text {th }}$ day for 14 days observation. The result showed that chopped banana stem contained active compounds of alkaloids (17.63\% flavonoids, $0.02 \%$ tannin and $0.24 \%$ saponins). Those active compounds increased the non-specific immune system including respiratory burst, lysozyme activity, phagocyte activity, erythrocyte, leucocyte, and haemoglobin. Treatment with a concentration of $5 \mathrm{~g} / \mathrm{L}$ and no replacement of the chopped banana stem was the best treatment with $75 \%$ relative percent survival. In addition, it also had highest phagocytes (36.3\%), respiratory burst (0.58 at O.D. 630), and lysozyme activity (72.7 unit $/ \mathrm{mL}$ ) after four days challenged with $S$. agalactiae.
\end{abstract}

Keywords: Banana stem, immunostimulant, Nile tilapia, non-specific immune system, Streptococcus agalatiae

\begin{abstract}
ABSTRAK
Penyakit streptococcosis disebabkan oleh S. agalactiae yang ditemukan pada ikan nila. Penelitian ini bertujuan menentukan konsentrasi dan frekuensi pergantian cacahan batang pisang sebagai imunostimulan untuk meningkatkan daya tahan tubuh ikan nila terhadap serangan penyakit streptococcosis. Penelitian ini menggunakan rancangan acak lengkap faktorial dengan dua faktor yaitu konsentrasi dan frekuensi pergantian cacahan batang pisang pada media pemeliharaan ikan dengan 11 perlakuan dan 3 ulangan. Konsentrasi batang pisang yang digunakan yaitu 5 $\mathrm{g} / \mathrm{L}, 10 \mathrm{~g} / \mathrm{L}$, dan $15 \mathrm{~g} / \mathrm{L}$, sedangkan frekuensi pergantian batang pisang dalam penelitian ini yaitu tiga hari, tujuh hari dan tanpa pergantian batang pisang. Perlakuan perendaman dengan cacahan batang pisang dilakukan selama 14 hari, kemudian dilakukan uji tantang dengan bakteri S. agalactiae pada hari ke-15 selama 14 hari pengamatan. Hasil penelitian menunjukkan bahwa cacahan batang pisang ambon mengandung senyawa aktif berupa alkaloid (flavonoid $17,63 \%$, tanin $0,02 \%$. dan saponin $0,24 \%$ ). Senyawa aktif tersebut mampu meningkatkan respons imun non-spesifik pada ikan nila yaitu respiratory burst, aktivitas lisozim, aktivitas fagositik, total leukosit, total eritrosit, dan hemoglobin. Perlakuan dengan konsentrasi $5 \mathrm{~g} / \mathrm{L}$ dan tanpa pergantian cacahan batang pisang merupakan perlakuan terbaik dengan nilai relative percent survival (RPS) mencapai $75 \%$, lebih besar dari perlakuan lainnya. Selain itu, perlakuan ini memiliki nilai tertinggi pada aktivitas fagositik (36,6\%), respiratory burst (0,58 pada O.D. $630 \mathrm{~nm})$ dan aktivitas lisozim $(72,7 \mathrm{unit} / \mathrm{mL})$ setelah hari ke-4 uji tantang dengan bakteri S. agalactiae.
\end{abstract}

Kata kunci: Batang pisang, ikan nila, imunostimulan, respons imun, Streptococcus agalactiae 


\section{INTRODUCTION}

Nirwana tilapia strain with high growth performance has low disease resistance (Alimuddin et al., 2015). Streptococcosis caused by the bacteria Streptococcus agalactiae is a type of disease that is often found in Nile tilapia farming in Indonesia, especially in West Java (Taukhid, 2014). It has high mortality rates up to $70 \%$ (Huang et al., 2013). S. agalactiae is a gram positive group bacteria, not motile, fermentatively positive and negative catalase (Hardi et al., 2008) which can infect freshwater and sea water fish, both wild and cultivated species (Yi et al., 2014).

Immunostimulants, vaccines, and probiotics are considered to be ideal and effective prevention in disease control strategies that support sustainability in aquaculture. Immunostimulant such as levamisole (Bedasso, 2017), $\beta$-glucan (Meena et al., 2013; Pilarski et al., 2017), peptidoglycans (Gan et al., 2016), chitin, chitosan (Harikrishnan et al., 2012; Abu-Elala et al., 2015), yeast, vitamin combinations, and phytopharmaca are biological components that potentially enhance the non-specific cellular and humoral defense mechanisms, the first line of defense against pathogens (Harikrishnan et al., 2011; Selim et al., 2014; Selim \& Rasha, 2015). Immunostimulant can be applied by injection, immersion, and oral (Harikrishnan et al., 2012). It depends on the time of application, dosage, the method used, and the physiological conditions of the fish (Rattanavichai et al., 2015).

Immunity is a resistance to infectious diseases, classified into non-specific and specific immune responses. The non-specific immune response is the first line of defense against pathogens (Hariskrishnan et al., 2012). The non-specific immune system consists of cellular defense mechanisms (macrophages, monocytes, granulocytes, non-specific cytotoxic cells and cell lines) and humoral defense mechanisms (lysozyme, complement, interferon, C-reactive protein, transferrin, and lectin) (Magnadottir, 2006). Immunostimulant, vaccines, and probiotics are believed to be ideal and effective disease control strategies that foster sustainability in aquaculture. The popularity of these alternatives was brought forth when the demand of antibiotics reduction arose because of uncontrolled use potentially lead to antibiotic resistance in bacteria, causing risks to the consumers and environment and for the development of an eco-friendly industry arose (Calbello, 2006; Abarike et al., 2018)
Banana stem (Musa paradisiaca) is one of the phytopharmaca that can be used as an immunostimulant for preventing pathogen infection. The survival rate after challenge tested by Aeromonas hydrophila in catfish through immersion of "kepok" banana stem $(75.0 \%)$ was higher than the control treatment $(25.0 \%)$ (Siregar et al., 2016). There is no previous study yet on the application of banana stem by immersion for Nile tilapia farming and the influence of it in the water. The dosage and replacement time interval is expected to determine the effectiveness and the efficiency of the chopped banana stem. Therefore, this study performed to determine the effective concentration and replacement time interval of the chopped banana stem as an immunostimulant to stimulate the non-specific immune system of Nile tilapia against $S$. agalactiae infection.

\section{MATERIALS AND METHODS}

\section{Experimental design}

This research was conducted using factorial completely randomized design. The treatments consisted of two factors; the concentration and the changing frequency (replacement time interval) of banana stem on Nile tilapia rearing media, then each treatment was given three replications (Table $1)$.

\section{Preparation of the chopped banana stem}

Ambon banana stem ( $M$. paradisiaca) obtained from the experimental pond in Babakan, Faculty of Fisheries and Marine Science, Bogor Agricultural University. The banana stem was selected from the harvested plant and it was chopped into 1-2 $\mathrm{cm}$ of its length, height, and width.

\section{Preparation of container and fish}

This study used 44 aquarium sizing of $65 \times 30 \times 35 \mathrm{~cm}^{3}$ with $45 \mathrm{~L}$ of water. Nirwana tilapia strain with body length of $8.67 \pm 0.18$ $\mathrm{cm}$ with body weight of: $12.10 \pm 0.95$ gram was derived from the study conducted by Alimuddin et al., (2015). Each aquarium filled with 20 fishes per unit treatment and fish fed on commercial diet with protein content of $28 \%$ twice a day to an apparently satiation.

Preparation of bacterial suspension of Streptococcus agalactiae and challenge test

S. agalactiae was obtained from Center for Research and Development of Freshwater 
Table 1. The treatment of chopped banana stem with different concentration and the frequency of replacement banana stem

\begin{tabular}{cccc}
\hline The treatment & Materials & $\begin{array}{c}\text { Concentration of } \\
\text { banana stem }(\mathrm{g} / \mathrm{L})\end{array}$ & $\begin{array}{c}\text { Replacement time interval } \\
(\text { days })\end{array}$ \\
\hline Negative control (C-) & Without banana stem & 0 & No replacement \\
Positive control (C+) & Without banana stem & 0 & No replacement \\
A 3 & Chopped of & 5 & 3 \\
B 3 & banana stem & 10 & 7 \\
C 3 & & 15 & \\
A 7 & Chopped of & 5 & No replacment \\
B 7 & banana stem & 10 & \\
C 7 & & 15 & \\
A 14 & Chopped of & 5 & 10 \\
B 14 & banana stem & 15 & \\
C 14 & & 10 & \\
\hline
\end{tabular}

Note : (A 3), (B 3), (C 3)= treatment of $5 \mathrm{~g} / \mathrm{L}, 10 \mathrm{~g} / \mathrm{L}, 15 \mathrm{~g} / \mathrm{L}$ concentrations with three days replacement time interval, and at the time of challenge test fish was injected with $S$. agalactiae; (A 7), (B 7), (C 7)= treatment of 5 $\mathrm{g} / \mathrm{L}, 10 \mathrm{~g} / \mathrm{L}, 15 \mathrm{~g} / \mathrm{L}$ concentrations with seven days replacement time interval, and at the time of challenge test fish was injected with $S$. agalactiae; (A 14), (B 14), (C 14)= treatment of $5 \mathrm{~g} / \mathrm{L}, 10 \mathrm{~g} / \mathrm{L}, 15 \mathrm{~g} / \mathrm{L}$ concentrations with no replacement of chopped banana, and at the time of challenge test fish was injected with $S$. agalactiae; $(\mathrm{C}+)=$ no banana stem added to rearing media and at the time of challenge test fish was injected with $S$. agalactiae; $(\mathrm{C}-)=$ no banana stem added to rearing media and at the time of challenge test fish was injected with PBS.

Aquaculture (BPPBIH), Depok. Virulance bacteria tested using Koch's postulates. The $\mathrm{LD}_{50}$ was determined before challenge test performed. Challenge test conducted by injecting S. agalactiae at a density of $10^{7} \mathrm{CFU} / \mathrm{mL}$ with a dose of $0.1 \mathrm{~mL} /$ fish through intraperitoneal injection. Changes occurred were observed and recorded for 14 days.

\section{Parameter of observation}

Qualitative and quantitative analysis of phytochemistry

The qualitative and quantitative analysis was conducted at Research Institute for Medicinal Plants and Spices, Bogor. Qualitative analysis of phytochemical was performed by following the procedure of Harborne (2006). Quantitative analysis for flavonoid and tannin were done through the method of spectrophotometry, while saponin was by thin-layer of chromatography scanner to calculate the amount of each active compound expressed as a percentage (\%).

\section{Survival rate}

The survival rate of tilapia was computed at day-14 after immersion and at day-14 after challenge test with $S$. agalactiae. The survival rate of tilapia was calculated according to Effendi (2004).

$$
\mathrm{SR}(\%)=\frac{\mathrm{Nt}}{\mathrm{No}} \times 100
$$

\section{Hematology and immune response}

Fish blood collection for hematology and immune response parameters conducted at day -14 after immersion and at day-14 after challenge test with $S$. agalactiae. The observed hematology and immune response observed were erythrocyte and leucocyte (Blaxhall \& Daisley, 1973), phagocytic activity (Anderson \& Siwicki, 1993), respiratory burst, and lysozyme activity (Wu et al., 2013).

\section{Clinical signs}

The observed clinical signs consisted of changes in fish behavior included a change in swimming habit, feeding response, and a change in external and internal anatomy (melanosis, exophthalmia, corneal opacity, purulence, scoliosis, and dropsi).

\section{Water quality}

Temperature and dissolved oxygen were measured daily by thermo scientific submersible dissolved oxygen probe DO 300 and $\mathrm{pH}$ were measured by Waterproof $\mathrm{pH}$ Testr ${ }^{\circledR} 30$. Measurement of hardness (titration) and total ammonia (spectrophotometer) was done every seven days, and the level of potassium and calcium (atomic absorption spectrophotometer) were measured at the beginning and the end of the study. 


\section{Data analysis}

Survival rate, immune responses, and hematology parameters were analyzed quantitatively by using Microsoft Excel 2010 and SPSS version 16.0. If the result of the ANOVA test was significantly different, post hoc test of Duncan was performed at $\mathrm{P}=0.05$. The data of clinical signs and water quality parameter were analyzed descriptively.

\section{RESULT AND DISCUSSION}

\section{Active compound content of ambon banana stem}

The result of the qualitative and quantitative analysis is shown in Table 2. The chopped banana stem contained active compounds of flavonoid $(17.63 \%)$, tannin $(0.02 \%)$, saponin $(0.24 \%)$, and alkaloid (Table 2).

Table 2. Qualitative and quantitative analysis of chopped banana stem

\begin{tabular}{lcc}
\hline \multirow{2}{*}{$\begin{array}{c}\text { Active } \\
\text { compound }\end{array}$} & \multicolumn{2}{c}{ Analysis method } \\
\cline { 2 - 3 } Alkaloid & Qualitative & Quantitative \\
Saponin & + & $\times$ \\
Tannin & + & 0.24 \\
Phenolic & + & 0.02 \\
Flavonoid & - & $\times$ \\
Terpenoids & + & 17.63 \\
Steroid & - & $\times$ \\
Glycoside & - & $\times$ \\
$(+)=$ detected; $(-)=$ not detected; $(\times)=$ quantitative \\
analysis are not performed
\end{tabular}

The previous stufy on phytochemical test of chopped ambon banana stem active compound in water showed that water added with the chopped banana stem of $5 \mathrm{~g} / \mathrm{L}, 10 \mathrm{~g} / \mathrm{L}$, and $15 \mathrm{~g} / \mathrm{L}$ contained flavonoid, respectively of $0.049 \%, 0.098 \%$, and $0.147 \%$, and phenolic in each concentration at day -7 of immersion. The result of the qualitative analysis in water added with chopped banana stem and fish indicated that only alkaloid was detected at the day-14 of immersion. It is expected that the amount of alkaloid compound in the water was higher compared to other active compounds, hence it was absorbed by the fish body, and the amount of alkaloid was still abundant in the water and was still able to be detected at day-14 of immersion. This finding was in line with the study conducted by Onyema et al., (2016) that alkaloid percentage in the banana stem $(8.16 \%)$ was higher than other active compounds such as flavonoid (4.02\%) and saponin (3.5\%). Another possibility is the fact that alkaloid is not easily dissolved in the water (Cushnie et al., 2014), while other active compounds (flavonoid, saponin, and tannin) is able to dissolve in the water (Cazzarolli et al., 2008) thus alkaloid durability in the water has a longer period of time compared to other active compounds.

\section{Survival rate of fish and water quality during immersion treatment}

The addition of chopped banana stem in the water did not affect the survival rate of tilapia during immersion, all fish survived in all treatments (SR 100\%). A similar result was also reported in catfish (Siregar et al., 2016). Thus, water quality during the immersion treatment in this study, namely: temperature $\left(26.00-27.28^{\circ} \mathrm{C}\right)$; pH (6.57-8.26); DO (4.16-7.44 mg/L); hardness (44.04-116.12 mg/L); and TAN (0.095-0.659 $\mathrm{mg} / \mathrm{L}$ ) was still within the ideal range for tilapia (Pandit \& Nakamura, 2010; El-Sherif \& Elfeky, 2009; Colt et al., 2011; Covalcante et al., 2009).

\section{The content of calcium and potassium in rearing media of tilapia}

Banana stem, besides containing active compounds, also has high mineral content, namely potassium and calcium. Potassium and calcium content of banana stem according to Poyyamozhi and Kadirvel (1986) are $95.34 \mathrm{~g} / \mathrm{kg}$ and 4.98 $\mathrm{g} / \mathrm{kg}$ of the fresh banana stem, respectively. Potassium functions as an antibacterial and antiinflammatory agent, improving metabolism and body organ function (Insana \& Wahyu, 2015) as well as help to maintain osmotic pressure and acid-base balance. Moreover, the addition of potassium together with hormone (insulin and thyroxine) is able to stimulate lymphocyte proliferation and against the pathogen (Hill et al., 2005). Furthermore, calcium is one of the components of the skeleton and cofactor of several types of enzymes such as $\mathrm{Na}^{+} / \mathrm{K}^{+}$ATP-ase and also plays in the process of osmoregulation and nerve activity. In addition, its administration with phorbol ester simultaneously can stimulate $\mathrm{T}$ cell and B cell in catfish (Lin et al., 1992). In this research, potassium content in the water at day-14 after banana stem immersion ranged from 11.2 to $61.5 \mathrm{mg} / \mathrm{L}$. Moreover, calcium content in the water at day-14 after banana stem immersion had a range from 5.0 to $9.2 \mathrm{mg} / \mathrm{L}$. Treatment with a concentration of $5 \mathrm{~g} / \mathrm{L}$ and no replacement of 

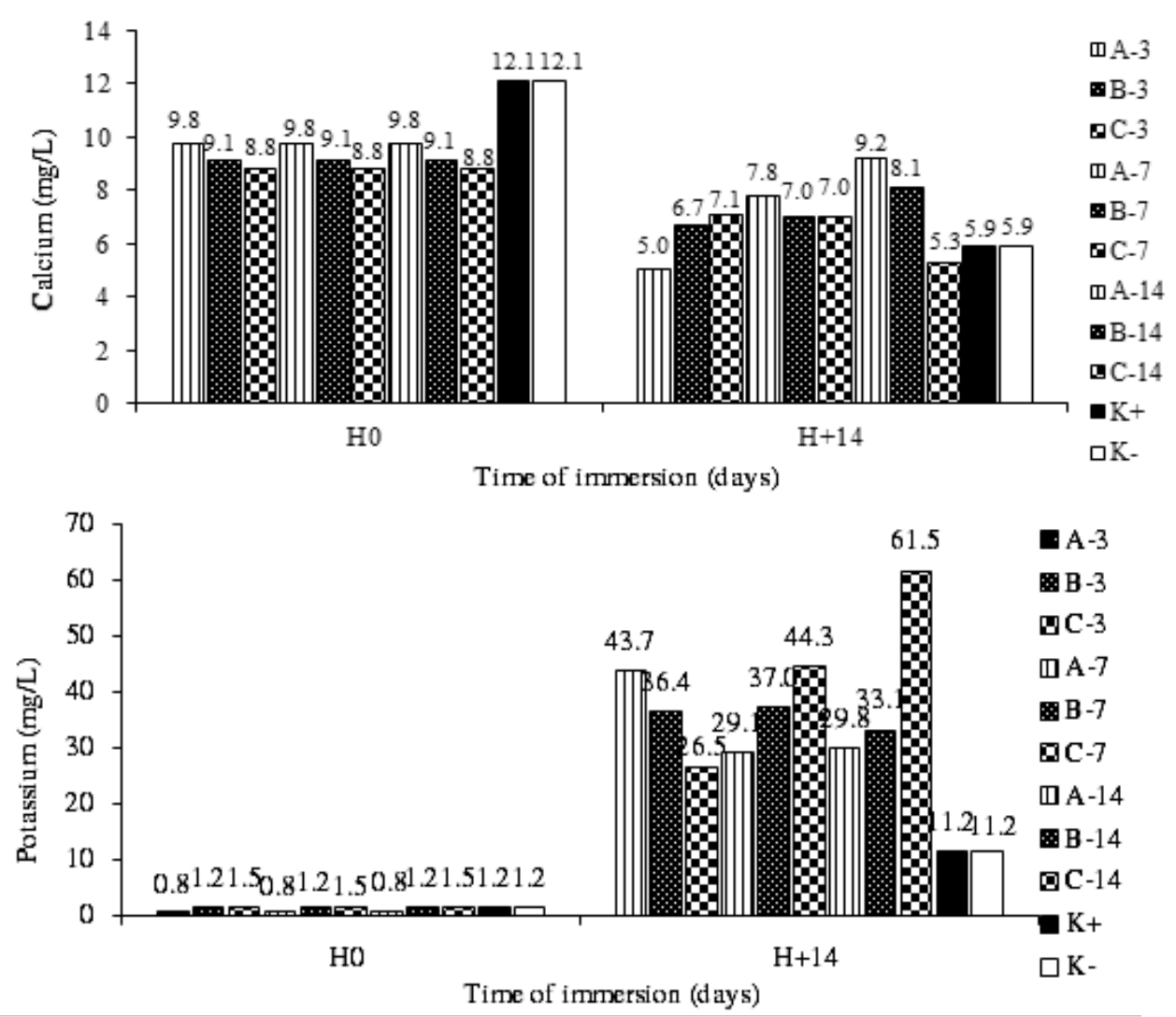

Figure 1. Calcium and potassium levels in water during the immersion of banana stem. $(\mathrm{A})=$ concentration $5 \mathrm{~g} / \mathrm{L}$; $(\mathrm{B})=$ concentration $10 \mathrm{~g} / \mathrm{L} ;(\mathrm{C})=$ concentration $15 \mathrm{~g} / \mathrm{L} ;(3)=3$ days replacement interval; $(7)=7$ days replacement interval; $(14)=$ no replacement of chopped banana; $(\mathrm{C}-)=$ negative control, no banana stem added to rearing media; $(\mathrm{C}+)=$ positive, control no banana stem added to rearing media.

chopped banana stem (A 14) generated the highest calcium content $(9.2 \mathrm{mg} / \mathrm{L})$.

\section{Survival rate of fish after challenge test with Streptococcus agalactiae}

In this study, the effect of the chopped banana stem on fish survival after challenging test with $S$. agalactiae was significant. The highest SR was obtained in treatment A 3 (banana stem concentration was $5 \mathrm{~g} / \mathrm{L}$ with three days replacement interval of banana stem: was $81.67 \pm 2.89 \%$ ) and A 14 (banana stem concentration was $5 \mathrm{~g} / \mathrm{L}$ with no replacement of chopped banana stem: was $85.00 \pm 0.00 \%$ ) and significantly different from other treatments, including treatment $\mathrm{C}+(40.00 \pm 5.00 \%)(\mathrm{P}<0.05$; Figure 2). The addition of banana stem at the highest concentration $(15 \mathrm{~g} / \mathrm{L})$ resulted in lower fish survival compared to other concentrations (5 $\mathrm{g} / \mathrm{L}$ and $10 \mathrm{~g} / \mathrm{L}$ ), except for the positive control, while the replacement time interval of was not affected. It is likely that alkaloid in high amount is toxic to fish. It means that alkaloid in a certain amount is not always toxic to fish, and may work synergically with other compounds (Queiroz et al., 2013). Survival rate after challenge test with
Aeromonas hydrophila in catfish with "kepok" banana stem through immersion (75.0\%) has also been reported to be higher than the control treatment (25.0\%) (Siregar et al., 2016).

\section{Hematology and immune responses Total erythrocyte and hemoglobin}

Total erythrocyte of tilapia after immersion with the chopped banana stem in each treatment at day-14 increased up to $13 \%$ compared to the control (Table 2). This increase was still within the normal range according to Bittencourt et al. (2003). Furthermore, the level of fish hemoglobin increased at day-14 after immersion with the chopped banana stem of $18 \%$ (Table 3). Total erythrocyte of tilapia after challenge test with $S$. agalactiae at day -4 had an average decline amounted to $20 \%$ of total erythrocyte after immersion. However, this was still within the normal range according to Bittencourt et al. (2003). The decrease of total erythrocyte in tilapia after challenge test with $S$. agalacitae followed with the declining level of tilapia hemoglobin to $33.3 \%$ from total hemoglobin level of fish after immersion (Table 3). The decrease in total erythrocyte count and hemoglobin after challenge 


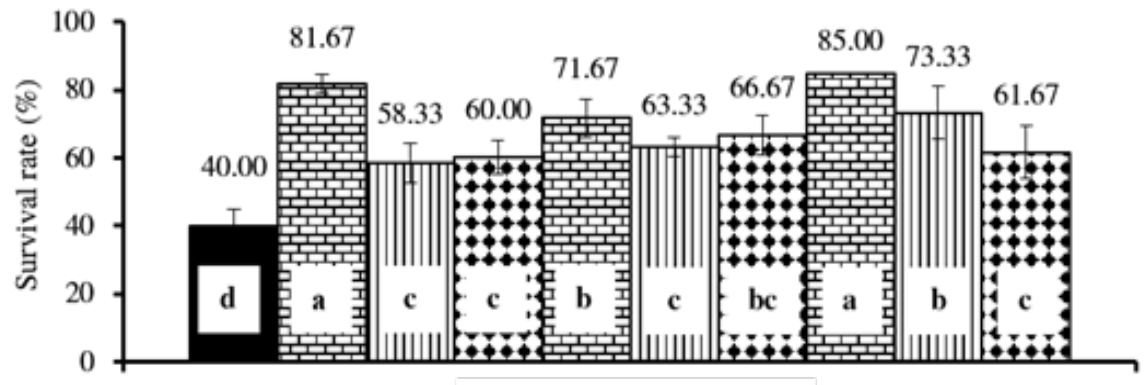

The effect of immersion

Figure 2. Survival rate $(\%)$ of tilapia after challenge test with Streptococcus agalactiae. $(\mathrm{A})=$ concentration $5 \mathrm{~g} / \mathrm{L}$; $(B)=$ concentration $10 \mathrm{~g} / \mathrm{L} ;(\mathrm{C})=$ concentration $15 \mathrm{~g} / \mathrm{L} ;(3)=3$ days replacement interval; $(7)=7$ days replacement interval; $(14)=14$ days replacement interval; no banana stem added to rearing media; $(\mathrm{C}+)=$ positive, control no banana stem added to rearing media. Different superscript letters in the bar graphic bar show significantly different values $(\mathrm{P}<0.05)$.

test that indicate anemia in fish was showed by hemorrhage on fish kidney (Hardi et al., 2011).

At day-12 after challenge test, the total erythrocyte and hemoglobin, respectively increased up to $21.7 \%$ and $50.0 \%$ of total fish erythrocyte and hemoglobin at day- 8 after challenge test (Table 3). Based on Hardi et al. (2011), the increase of total erythrocyte indicated a homeostatic effort of fish to produce more blood cell, and replace erythrocyte lysis due to infection. Yunita et al. (2016) stated that flavonoid and other active compounds in banana stem might help in improving and activating damaged of hemoglobin. Moreover, An et al. (2015) mentioned that flavonoid might inhibit the occurrence of hemolysis in erythrocyte.

\section{Total leucocyte and phagocytic activity (PA)}

Total leucocyte increased of $32 \%$ compared to the control treatment at day-14 after immersion (Table 4). Based on Nugroho et al. (2016), flavonoid can have a function as biocatalysator for leucocyte production and stimulate leucocyte as non-specific cellular immunity. Increased total leucocyte has an impact on phagocytic activity. In this study, the phagocytic activity value had

Table 3. Total erythrocyte $\left(\times 10^{6}\right.$ cell $\left./ \mathrm{mm}^{3}\right)$ and hemoglobin $(\mathrm{g} / \mathrm{dL})$ in tilapia after immersion $(\mathrm{H}+14)$ dan postchallenge with $S$. agalactiae $(\mathrm{H}+4, \mathrm{H}+8$, and $\mathrm{H}+12)$

\begin{tabular}{|c|c|c|c|c|c|c|c|c|}
\hline \multirow{3}{*}{ Treatment } & \multirow{2}{*}{\multicolumn{2}{|c|}{$\begin{array}{c}\text { After immersion } \\
\mathrm{H}+14\end{array}$}} & \multicolumn{6}{|c|}{ After challenge test with $S$. agalactiae } \\
\hline & & & \multicolumn{2}{|c|}{$\mathrm{H}+4$} & \multicolumn{2}{|c|}{$\mathrm{H}+8$} & \multicolumn{2}{|c|}{$\mathrm{H}+12$} \\
\hline & $\mathrm{Hb}$ & Erythrocyte & $\mathrm{Hb}$ & Erythrocyte & $\mathrm{Hb}$ & Erythrocyte & $\mathrm{Hb}$ & Erythrocyte \\
\hline $\mathrm{C}-$ & $6.7 \pm 0.1^{\mathrm{d}}$ & $2.3 \pm 0.2^{\mathrm{efg}}$ & $5.0 \pm 0.0^{\mathrm{cd}}$ & $3.4 \pm 0.0^{\mathrm{a}}$ & $6.2 \pm 0.5^{\mathrm{b}}$ & $3.2 \pm 0.0^{\mathrm{a}}$ & $9.1 \pm 0.2^{\mathrm{a}}$ & $3.1 \pm 0.0^{\mathrm{a}}$ \\
\hline $\mathrm{C}+$ & $6.3 \pm 0.2^{\mathrm{d}}$ & $2.3 \pm 0.2^{\mathrm{efg}}$ & $4.3 \pm 0.1^{\mathrm{ef}}$ & $1.1 \pm 0.1^{\mathrm{f}}$ & $4.7 \pm 0.3^{\mathrm{c}}$ & $1.0 \pm 0.0^{\mathrm{g}}$ & $5.7 \pm 0.9^{a}$ & $2.2 \pm 0.1^{\mathrm{cd}}$ \\
\hline A3 & $7.6 \pm 0.2^{\mathrm{bc}}$ & $2.1 \pm 0.2^{\mathrm{fg}}$ & $6.0 \pm 0.3^{\mathrm{a}}$ & $1.7 \pm 0.2^{\mathrm{cd}}$ & $7.9 \pm 0.1^{\mathrm{a}}$ & $1.7 \pm 0.1^{\mathrm{d}}$ & $7.6 \pm 0.3^{\mathrm{a}}$ & $1.2 \pm 0.0^{\mathrm{g}}$ \\
\hline B3 & $7.5 \pm 0.2^{\mathrm{bc}}$ & $2.4 \pm 0.2^{\mathrm{ef}}$ & $4.9 \pm 0.6^{\mathrm{cd}}$ & $2.5 \pm 0.2^{\mathrm{b}}$ & $4.4 \pm 0.3^{\mathrm{cd}}$ & $1.5 \pm 0.0^{\mathrm{e}}$ & $7.7 \pm 0.9^{a}$ & $1.8 \pm 0.1^{\mathrm{f}}$ \\
\hline $\mathrm{C} 3$ & $9.4 \pm 0.3^{\mathrm{a}}$ & $3.8 \pm 0.0^{\mathrm{a}}$ & $5.3 \pm 0.1^{\mathrm{bc}}$ & $1.3 \pm 0.2^{\mathrm{ef}}$ & $3.5 \pm 0.4^{\mathrm{ef}}$ & $1.1 \pm 0.1^{\mathrm{g}}$ & $6.0 \pm 0.2^{\mathrm{a}}$ & $2.0 \pm 0.1^{\mathrm{e}}$ \\
\hline A7 & $7.4 \pm 0.3^{c}$ & $2.1 \pm 0.1^{\mathrm{fg}}$ & $4.1 \pm 0.1^{\mathrm{ef}}$ & $1.5 \pm 0.3^{\mathrm{de}}$ & $4.3 \pm 0.4^{\mathrm{cd}}$ & $1.4 \pm 0.2^{\mathrm{f}}$ & $8.7 \pm 0.3^{\mathrm{a}}$ & $2.6 \pm 0.3^{b}$ \\
\hline B7 & $7.6 \pm 0.2^{\mathrm{bc}}$ & $2.4 \pm 0.1^{\text {de }}$ & $4.1 \pm 0.1^{\mathrm{ef}}$ & $2.3 \pm 0.2^{\mathrm{b}}$ & $4.0 \pm 0.0^{\mathrm{de}}$ & $1.7 \pm 0.2^{\mathrm{d}}$ & $7.9 \pm 0.1^{\mathrm{a}}$ & $2.1 \pm 0.2^{\mathrm{de}}$ \\
\hline $\mathrm{C} 7$ & $8.1 \pm 0.9^{\mathrm{b}}$ & $3.2 \pm 0.3^{\mathrm{b}}$ & $4.1 \pm 0.2^{\mathrm{f}}$ & $1.8 \pm 0.2^{\mathrm{c}}$ & $3.4 \pm 0.0^{\mathrm{f}}$ & $2.4 \pm 0.0^{c}$ & $6.5 \pm 0.3^{\mathrm{a}}$ & $2.2 \pm 0.1^{\text {cde }}$ \\
\hline A14 & $7.9 \pm 0.1^{\mathrm{bc}}$ & $3.1 \pm 0.2^{\mathrm{bc}}$ & $5.8 \pm 0.4^{\mathrm{ab}}$ & $2.4 \pm 0.2^{\mathrm{b}}$ & $4.7 \pm 0.1^{\mathrm{c}}$ & $2.5 \pm 0.1^{\mathrm{b}}$ & $8.8 \pm 0.5^{\mathrm{a}}$ & $2.4 \pm 0.1^{\mathrm{c}}$ \\
\hline B14 & $7.5 \pm 0.5^{\mathrm{bc}}$ & $2.9 \pm 0.2^{\mathrm{cd}}$ & $4.7 \pm 0.4^{\mathrm{de}}$ & $1.1 \pm 0.1^{\mathrm{f}}$ & $4.4 \pm 0.2^{\mathrm{cd}}$ & $1.5 \pm 0.0^{\text {ef }}$ & $7.1 \pm 0.6^{\mathrm{a}}$ & $1.7 \pm 0.1^{\mathrm{f}}$ \\
\hline $\mathrm{C} 14$ & $6.4 \pm 0.4^{\mathrm{d}}$ & $1.9 \pm 0.0^{\mathrm{g}}$ & $5.1 \pm 0.7^{\mathrm{cd}}$ & $1.6 \pm 0.2^{\mathrm{cde}}$ & $4.6 \pm 0.1^{\mathrm{cd}}$ & $1.2 \pm 0.0^{\mathrm{g}}$ & $5.9 \pm 0.1^{\mathrm{a}}$ & $1.6 \pm 0.1^{\mathrm{f}}$ \\
\hline
\end{tabular}
different $(\mathrm{P}<0,05)$. $(\mathrm{A})=$ concentration $5 \mathrm{~g} / \mathrm{L} ;(\mathrm{B})=$ concentration $10 \mathrm{~g} / \mathrm{L} ;(\mathrm{C})=$ concentration $15 \mathrm{~g} / \mathrm{L} ;(3)=3$ days replacement interval; $(7)=7$ days replacement interval; $(14)=$ no replacement of chopped banana stem; $(C+)=$ positive control (no banana stem added to rearing media). (C-)= negative control (no banana stem added to rearing media). 
Table 4. Total leucocyte $\left(\times 10^{4} \mathrm{cell} / \mathrm{mm}^{3}\right)$ and phagocytic activity $(\%)$ of tilapia after immersion $(\mathrm{H}+14)$ and postchallenge with $S$. agalactiae $(\mathrm{H}+4, \mathrm{H}+8$, and $\mathrm{H}+12)$

\begin{tabular}{|c|c|c|c|c|c|c|c|c|}
\hline \multirow{3}{*}{ Treatment } & \multirow{2}{*}{\multicolumn{2}{|c|}{$\begin{array}{c}\text { After immersion } \\
\mathrm{H}+14\end{array}$}} & \multicolumn{6}{|c|}{ After challenge test with $S$. agalactiae } \\
\hline & & & \multicolumn{2}{|c|}{$\mathrm{H}+4$} & \multicolumn{2}{|c|}{$\mathrm{H}+8$} & \multicolumn{2}{|c|}{$\mathrm{H}+12$} \\
\hline & Leucocyte & PA & Leucocyte & PA & Leucocyte & $\mathrm{PA}$ & Leucocyte & PA \\
\hline $\mathrm{C}-$ & $6.1 \pm 0.2^{\mathrm{g}}$ & $24.2 \pm 0.9^{\mathrm{a}}$ & $8.4 \pm 0.3^{\mathrm{d}}$ & $25.0 \pm 1.8^{\mathrm{f}}$ & $4.2 \pm 2.1^{\mathrm{g}}$ & $24.8 \pm 1.3^{\mathrm{a}}$ & $5.9 \pm 0.0^{\mathrm{g}}$ & $26.5 \pm 1.3^{\mathrm{a}}$ \\
\hline $\mathrm{C}+$ & $6.8 \pm 0.2^{\mathrm{f}}$ & $24.3 \pm 0.9^{a}$ & $7.2 \pm 0.6^{\mathrm{e}}$ & $28.0 \pm 0.8^{\mathrm{e}}$ & $6.6 \pm 2.5^{\mathrm{f}}$ & $27.0 \pm 1.4^{\mathrm{a}}$ & $5.5 \pm 0.1^{g}$ & $27.5 \pm 1.3^{\mathrm{a}}$ \\
\hline A 3 & $8.5 \pm 0.6^{\mathrm{cb}}$ & $26.3 \pm 2.2^{\mathrm{a}}$ & $10.2 \pm 0.2^{c}$ & $31.0 \pm 1.8^{\mathrm{cd}}$ & $11.6 \pm 0.3^{\mathrm{a}}$ & $33.3 \pm 1.3^{\mathrm{a}}$ & $10.4 \pm 0.3^{\mathrm{a}}$ & $36.0 \pm 1.8^{\mathrm{a}}$ \\
\hline B 3 & $7.4 \pm 0.2^{\mathrm{de}}$ & $28.8 \pm 0.9^{\mathrm{a}}$ & $11.2 \pm 0.1^{\mathrm{ab}}$ & $32.0 \pm 2.2^{\mathrm{bcd}}$ & $10.6 \pm 0.3^{b}$ & $34.3 \pm 1.5^{\mathrm{a}}$ & $9.3 \pm 0.3^{\mathrm{cd}}$ & $34.0 \pm 1.2^{\mathrm{a}}$ \\
\hline $\mathrm{C} 3$ & $9.7 \pm 0.5^{\mathrm{a}}$ & $28.3 \pm 2.1^{\mathrm{a}}$ & $11.1 \pm 0.9^{\mathrm{ab}}$ & $33.8 \pm 1.5^{\mathrm{abc}}$ & $11.5 \pm 0.3^{\mathrm{a}}$ & $34.8 \pm 0.5^{\mathrm{a}}$ & $6.4 \pm 0.3^{f}$ & $34.3 \pm 0.9^{a}$ \\
\hline A 7 & $7.6 \pm 0.3^{\mathrm{d}}$ & $30.3 \pm 2.4^{a}$ & $11.3 \pm 0.3^{\mathrm{ab}}$ & $35.8 \pm 2.9^{a}$ & $10.3 \pm 0.4^{\mathrm{b}}$ & $34.8 \pm 2.1^{\mathrm{a}}$ & $9.7 \pm 0.2^{\mathrm{bc}}$ & $37.0 \pm 0.8^{a}$ \\
\hline B 7 & $9.7 \pm 0.1^{\mathrm{a}}$ & $31.0 \pm 0.8^{\mathrm{a}}$ & $11.5 \pm 0.3^{\mathrm{a}}$ & $32.8 \pm 2.1^{\mathrm{bcd}}$ & $9.1 \pm 0.7^{\mathrm{c}}$ & $36.3 \pm 0.9^{a}$ & $5.9 \pm 0.8^{\mathrm{g}}$ & $35.5 \pm 2.1^{\mathrm{a}}$ \\
\hline C 7 & $7.0 \pm 0.3^{\mathrm{ef}}$ & $30.8 \pm 1.7^{a}$ & $10.6 \pm 0.3^{\mathrm{bc}}$ & $30.5 \pm 1.0^{\mathrm{de}}$ & $9.5 \pm 0.1^{\mathrm{c}}$ & $35.3 \pm 0.5^{\mathrm{a}}$ & $8.9 \pm 0.1^{\mathrm{de}}$ & $35.3 \pm 0.9^{a}$ \\
\hline A 14 & $9.7 \pm 0.1^{\mathrm{a}}$ & $30.5 \pm 1.7^{a}$ & $11.4 \pm 0.2^{\mathrm{ab}}$ & $36.3 \pm 2.2^{\mathrm{a}}$ & $8.4 \pm 0.4^{\mathrm{d}}$ & $34.8 \pm 2.1^{\mathrm{a}}$ & $9.7 \pm 0.1^{\mathrm{b}}$ & $38.3 \pm 2.6^{\mathrm{a}}$ \\
\hline B 14 & $8.9 \pm 0.4^{b}$ & $29.8 \pm 1.5^{\mathrm{a}}$ & $10.6 \pm 0.7^{\mathrm{bc}}$ & $34.5 \pm 2.7^{\mathrm{ab}}$ & $8.0 \pm 0.8^{\mathrm{de}}$ & $36.5 \pm 2.4^{\mathrm{a}}$ & $8.8 \pm 0.1^{\mathrm{e}}$ & $35.8 \pm 2.2^{\mathrm{a}}$ \\
\hline C 14 & $8.1 \pm 0.2^{\mathrm{c}}$ & $30.3 \pm 0.9^{a}$ & $11.5 \pm 0.3^{\mathrm{a}}$ & $32.0 \pm 1.8^{\mathrm{bcd}}$ & $7.5 \pm 0.2^{\mathrm{e}}$ & $33.5 \pm 1.3^{\mathrm{a}}$ & $10.3 \pm 0.3^{\mathrm{a}}$ & $33.3 \pm 0.9^{\mathrm{a}}$ \\
\hline
\end{tabular}

Reference: $\quad 2-15\left(\times 10^{4}\right.$ cell $\left./ \mathrm{mm}^{3}\right)$ Leucocyte (Svobodova \& Vyukusova, 1991)

Data were expressed as mean \pm standard deviation. Different superscript on the same coloum showed significantly different $(\mathrm{P}<0.05)$. $(\mathrm{A})=$ concentration $5 \mathrm{~g} / \mathrm{L} ;(\mathrm{B})=$ concentration $10 \mathrm{~g} / \mathrm{L} ;(\mathrm{C})=$ concentration $15 \mathrm{~g} / \mathrm{L} ;(3)=3$ days replacement interval; $(7)=7$ days replacement interval; $(14)=$ no replacement of chopped banana stem; $(\mathrm{C}+)=$ positive control (no banana stem added to rearing media). $(\mathrm{C}-$ )= negative control (no banana stem added to rearing media).

Table 5. Respiratory burst (O.D at $630 \mathrm{~nm})$ and lysozyme activity (unit/mL) of tilapia after immersion $(\mathrm{H}+14)$ and post-challenge with $S$. agalactiae $(\mathrm{H}+4, \mathrm{H}+8$, and $\mathrm{H}+12)$

\begin{tabular}{|c|c|c|c|c|c|c|c|c|}
\hline \multirow{3}{*}{ Treatment } & \multirow{2}{*}{\multicolumn{2}{|c|}{$\begin{array}{c}\text { After immersion } \\
\mathrm{H}+14 \\
\end{array}$}} & \multicolumn{6}{|c|}{ After challenge test with $S$. agalactiae } \\
\hline & & & \multicolumn{2}{|c|}{$\mathrm{H}+4$} & \multicolumn{2}{|c|}{$\mathrm{H}+8$} & \multicolumn{2}{|c|}{$\mathrm{H}+12$} \\
\hline & $\mathrm{RB}$ & Lysozyme & $\mathrm{RB}$ & Lysozyme & $\mathrm{RB}$ & Lysozyme & $\mathrm{RB}$ & Lysozyme \\
\hline $\mathrm{C}-$ & $0.14 \pm 0.01^{\mathrm{f}}$ & $18.1 \pm 0.8^{\mathrm{g}}$ & $0.40 \pm 0.02^{\mathrm{de}}$ & $16.9 \pm 0.7^{\mathrm{h}}$ & $0.23 \pm 0.01^{\mathrm{bc}}$ & $20.5 \pm 2.9^{g}$ & $0.19 \pm 0.00^{\text {de }}$ & $22.0 \pm 1.9^{\mathrm{h}}$ \\
\hline $\mathrm{C}+$ & $0.13 \pm 0.00^{\mathrm{f}}$ & $18.1 \pm 0.8^{\mathrm{g}}$ & $0.22 \pm 0.02^{\mathrm{f}}$ & $21.8 \pm 2.3^{\mathrm{g}}$ & $0.23 \pm 0.02^{\mathrm{bc}}$ & $22.8 \pm 0.2^{\mathrm{fg}}$ & $0.22 \pm 0.02^{\mathrm{bc}}$ & $31.6 \pm 0.9^{\mathrm{g}}$ \\
\hline A3 & $0.19 \pm 0.01^{\mathrm{cd}}$ & $45.8 \pm 1.9^{\mathrm{c}}$ & $0.25 \pm 0.03^{\mathrm{f}}$ & $31.7 \pm 2.4^{\mathrm{de}}$ & $0.21 \pm 0.01^{\mathrm{de}}$ & $31.6 \pm 2.2^{\mathrm{cd}}$ & $0.17 \pm 0.01^{\mathrm{fg}}$ & $44.9 \pm 3.2^{\mathrm{b}}$ \\
\hline B3 & $0.18 \pm 0.00^{\mathrm{d}}$ & $37.8 \pm 0.7^{\mathrm{e}}$ & $0.44 \pm 0.02^{\mathrm{b}}$ & $32.3 \pm 3.5^{\mathrm{de}}$ & $0.22 \pm 0.00^{\mathrm{cd}}$ & $26.9 \pm 1.7^{\text {ef }}$ & $0.15 \pm 0.00^{g}$ & $43.2 \pm 3.3^{\mathrm{bc}}$ \\
\hline $\mathrm{C} 3$ & $0.18 \pm 0.00^{\mathrm{d}}$ & $36.0 \pm 2.8^{\mathrm{e}}$ & $0.46 \pm 0.06^{\mathrm{b}}$ & $33.8 \pm 1.4^{\mathrm{de}}$ & $0.25 \pm 0.01^{\mathrm{ab}}$ & $28.4 \pm 2.5^{\mathrm{de}}$ & $0.16 \pm 0.01^{\mathrm{fg}}$ & $33.6 \pm 0.8^{\mathrm{fg}}$ \\
\hline A7 & $0.24 \pm 0.03^{\mathrm{a}}$ & $66.1 \pm 2.1^{\mathrm{a}}$ & $0.43 \pm 0.05^{\mathrm{bc}}$ & $59.5 \pm 2.1^{b}$ & $0.20 \pm 0.00^{\mathrm{e}}$ & $32.9 \pm 2.8^{c}$ & $0.21 \pm 0.01^{\mathrm{cd}}$ & $38.4 \pm 1.5^{\mathrm{de}}$ \\
\hline B7 & $0.22 \pm 0.01^{b}$ & $53.2 \pm 1.8^{\mathrm{b}}$ & $0.24 \pm 0.01^{\mathrm{f}}$ & $35.2 \pm 2.7^{\mathrm{d}}$ & $0.21 \pm 0.01^{\mathrm{de}}$ & $37.3 \pm 3.0^{\mathrm{b}}$ & $0.19 \pm 0.00^{\mathrm{de}}$ & $37.2 \pm 1.0^{\text {def }}$ \\
\hline $\mathrm{C} 7$ & $0.20 \pm 0.00^{\mathrm{b}}$ & $31.6 \pm 1.6^{f}$ & $0.35 \pm 0.06^{\text {cde }}$ & $44.2 \pm 3.3^{c}$ & $0.22 \pm 0.01^{\mathrm{cd}}$ & $32.7 \pm 2.2^{\mathrm{c}}$ & $0.18 \pm 0.02^{\mathrm{ef}}$ & $35.1 \pm 1.8^{\mathrm{efg}}$ \\
\hline A14 & $0.16 \pm 0.00^{e}$ & $37.5 \pm 0.9^{e}$ & $0.58 \pm 0.02^{\mathrm{a}}$ & $72.7 \pm 1.4^{\mathrm{a}}$ & $0.25 \pm 0.00^{\mathrm{ab}}$ & $41.8 \pm 1.7^{\mathrm{a}}$ & $0.26 \pm 0.01^{\mathrm{a}}$ & $51.4 \pm 3.9^{a}$ \\
\hline B14 & $0.18 \pm 0.01^{\mathrm{d}}$ & $32.2 \pm 1.3^{\mathrm{f}}$ & $0.28 \pm 0.01^{\mathrm{ef}}$ & $29.8 \pm 3.1^{\mathrm{ef}}$ & $0.26 \pm 0.01^{\mathrm{a}}$ & $35.1 \pm 3.5^{\mathrm{bc}}$ & $0.24 \pm 0.01^{\mathrm{b}}$ & $40.8 \pm 3.2^{\mathrm{cd}}$ \\
\hline $\mathrm{C} 14$ & $0.18 \pm 0.00^{\text {cd }}$ & $42.9 \pm 2.7^{\mathrm{d}}$ & $0.41 \pm 0.01^{\text {bcd }}$ & $27.4 \pm 1.8^{\mathrm{f}}$ & $0.26 \pm 0.01^{\mathrm{a}}$ & $34.7 \pm 2.9^{\mathrm{bc}}$ & $0.22 \pm 0.02^{\mathrm{bc}}$ & $36.6 \pm 2.5^{\mathrm{ef}}$ \\
\hline
\end{tabular}

Data were expressed as mean \pm standard deviation. Different superscript on the same coloum showed significantly different $(\mathrm{P}<0.05)$. $(\mathrm{A})=$ concentration $5 \mathrm{~g} / \mathrm{L} ;(\mathrm{B})=$ concentration $10 \mathrm{~g} / \mathrm{L} ;(\mathrm{C})=$ concentration $15 \mathrm{~g} / \mathrm{L} ;(3)=3$ days replacement interval; $(7)=7$ days replacement interval; $(14)=$ no replacement of chopped banana stem; $(\mathrm{C}+)=$ positive control (no banana stem added to rearing media). (C-)= negative control (no banana stem added to rearing media).

an increase up to $21 \%$ compared to the control at day-14 after immersion (Table 4).

Total leucocyte of tilapia at day-4 postchallenge with $S$. agalactiae experienced an average increase amounted to $27.3 \%$ of total leucocyte after immersion (Table 4). According to Hardi et al. (2011), infection of S. agalactiae can cause fish sending more leucocyte cell to the area of infection as a defensive effort. The value of phagocytic activity in tilapia at day-4 after challenge test increased to $11.8 \%$ of phagocytic activity percentage after immersion. This increase occurred continuously to occur at day-12 after challenge test. 

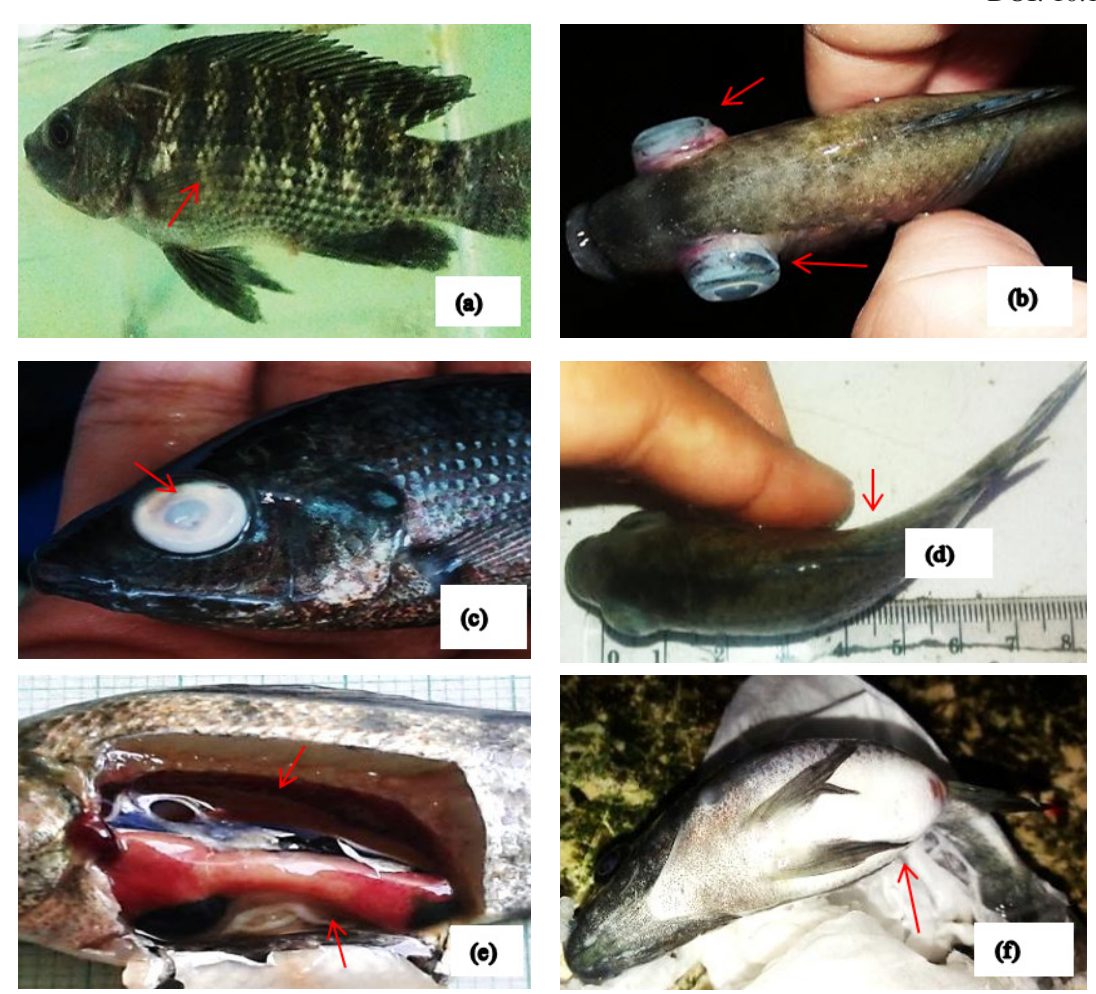

Figure 3. Clinical signs. $(a)=$ melanosis; $(b)=$ exophthalmia and corneal opacity; $(c)=$ purulens; $(d)=$ scoliosis; $(e)=$ haemorrhage in the liver and gallbladder; (f)= dropsi.

\section{Respiratory burst and (RB) and lysozyme activity}

The RB value increased to $43 \%$ compared to control at day-14 after immersion. Furthermore, lysozyme activity also had an increase to $57 \%$ compared to control at day-14 after immersion (Table 5). The RB value post-challenge at day4 had an increase to $100 \%$ of the previous RB value, with treatment $\mathrm{A}-14(0.58 \pm 0.02 \%)$ as treatment with the highest $\mathrm{RB}$ value $(\mathrm{P}<0.05)$. The increase of lysozyme activity also occurred in the highest activity was found at day- 4,8 , and 12 after challenge test with $S$. agalactiae, that was A-14 treatment (concentration of $5 \mathrm{~g} / \mathrm{L}$ and no replacement of chopped banana stem) which was $72.7 \pm 1.4,41.8 \pm 1.7$, and $51.4 \pm 3.9$, respectively (Table 4). The addition of banana stem in the water may increase proliferation of leucocyte cell and the amount of leucocyte cell in secreting lysozyme, so the level of lysozyme will further increase (Nugroho et al., 2016).

\section{Clinical signs}

In this research, clinical signs observed in tilapia after challenge test with $S$. agalactiae were the same as reported by Li et al. (2013); and Jantrakajorn et al., (2014). Those clinical symptoms were: whirling and fish did not actively swim, melanosis, exophthalmia, corneal opacity, purulent, clear operculum, scoliosis, and dropsy.

High level of survival rate and immune response that was achieved after challenge test with $S$. agalactiae in each immersion treatment proved that there were an optimal concentration and frequency of chopped banana stem replacement obtained from the active compound in the banana stem. It was expected S. agalactiae that entered the fish body was failed to be virulence due to the active compound of alkaloid can have a function as antibacterial agent, able to disrupt the virulence gene regulation, inhibit sorase, disrupt fimbriae and other adhesions, inhibit bacterial defenses against the host immune system, inhibit secretion system of bacteria, inhibit the destructive enzyme-mediated effect, and inhibit exotoxin-mediated effect (Cushnie et al., 2014). Antibacterial property is also found in the phenolic compound and it is able to inhibit the growth of bacteria through the secretion of inhibitor enzyme and oxidation of pathogen (Santangelo et al., 2007). In addition, flavonoid plays a role as an anti-inflammatory agent by inhibiting the release of histamine from mast cell, inhibit biosynthesis of prostanoid, inhibit phosphodiesterases, inhibit protein kinases, and activation of transcription (Rathee et al., 2009). Therefore, tilapia at day-12 after the challenge test was already in normal condition based on the data of total erythrocyte and hemoglobin (Table 
3).

Concentration treatment of $5 \mathrm{~g} / \mathrm{L}$ with no replacement of chopped banana stem (A 14) was the best treatment in this study. It was because treatment A 14 produced the higher survival rate and immune response, and also considered to be more efficient using the banana stem, it was $213.875 \mathrm{~g}$ as well as required less effort to provide the banana stem. In further study, it is required to test whethter lower level of banana stem than $5 \mathrm{~g} / \mathrm{L}$ allows higher immune response and fish survival, apply the results of this study in pond until fish reach a marketable size (about $200 \mathrm{~g}$ ), to assess the durability period from the effect of banana stem active compound after immersion in the fish body and to assess the mechanism of active compound durability in the water, particularly the fish rearing media.

\section{CONCLUSION}

The addition of the chopped banana stem into rearing media was able to affect immune response and survival of tilapia. Moreover, the concentration treatment of $5 \mathrm{~g} / \mathrm{L}$ and no replacement of chopped banana stem was the best treatment.

\section{REFERENCES}

Abarike ED, Jian J, Tang J, Cai J, Yu H, Lihua C, Jun L. 2018. Influence of traditional chinese medicine and Bacillus species (TCMBS) on growth, immune response and disease resistance in Nile tilapia, Oreochromis niloticus. Aquaculture Research 49: 2366-2375.

Abu-Elala NM,Mohamed SH, Zaki MM, Eissa AE. 2015. Assessment of the immunemodulatory and antimicrobial effects of dietary chitosan on Nile tilapia Oreochromis niloticus with special emphasis to its bio-remediating impacts. Fish \& Shelfish Immunology 46: 678-685.

Alimuddin, Nurjanah L, Nuryati S, Hardianto D. 2015. Growth performance and Streptococcosis disease resistance of Nile tilapia Oreochromis niloticus first generation selected by MHC I marker. [Prosiding Forum Inovasi Teknologi Akuakultur 2015]. Jakarta, Pusat Penelitian dan Pengembangan Perikanan Budidaya.

An F, Cao X, Qu H, Wang S. 2015. Attenuation of oxidative stress of erythrocytes by the plant-derived flavonoids vitexin and apigenin. Pharmazie 70: 724-732.

Anderson DP, Siwicki AK. 1993. Basic hematology and serology for fish health programs. [Symposium on Diseases in Asian Aquaculture "Aquatic Animal Health and the Evironment"]. Phuket, Thailand 17: 25-29.

Bedasso GT. 2017. A study of immune response in nile tilapia Oreochromis niloticus fed levamisole incorporated diet. Journal of Fisheries and Aquaculture Development 2017: 106.

Bittencourt NLR, Molinari LM, Scoaris DO, Pedroso RB, Nakamura CV, UedaNakamura T, Filho BAA, Filho BPD. 2003. Haematological and biochemical values for Nile tilapia Oreochromis niloticus cultures in semi-intensive system. Maringa 25: 385-389.

Blaxhall PC, Daisley KW. 1973. Routine haematological methods for use with fish blood. Journal Fish Biology 5: 577-581.

Calbello FC. 2006. Heavy use of prophylactic antibiotics in aquaculture: a growing problem for human and animal health and for the environment. Environmental Microbiology 8: 1137-1144.

Cushnie TPT, Cushnie B, Lamb AJ. 2014. Alkaloids: an overview of their antibacterial, antibiotic-enhancing and antivirulence activities. International Journal of Antimicrobial Agents 44: 377-386.

Colt J, Momoda T, Chitwood R, Fornshell G, Scherck C. 2011. Water quality in tilapia transport: from the farm to the retail store [communication]. North American Journal of Aquaculture 73: 426-434.

Covalcante dHD, Piliato dSA, Ribeiro CD, Magalhaes BF, Carmo dSMV. 2009. Effects of $\mathrm{CaCO}_{3}$ liming on water quality and growth performance of fingerlings of Nile tilapia Oreochromis niloticus. Animal Science 31: 327-333.

Effendi I. 2004. Pengantar Akuakultur. Depok. Penebar Swadaya.

El-Sherif SA, El-Gohary FA, Naser FA, Van DSP, Gijzen HJ. 2007. Nitrogen recovery in an integrated system for wastewater treatment and tilapia production. Environmentalist 27: 287-302.

El-Sherif MS, El-feky AMI. 2009. Performance of nile tilapia Oreochromis niloticus fingerlings. I. Effect of $\mathrm{pH}$. International Journal of Agriculture \& Biology 11: 297-300.

Gan Z, Chen S, Hou J, Huo H, Zhang X, Ruan B, Laghari ZA, Li L, Lu Y, Nie P. 2016. Molecular and functional characterization of peptidoglycan-recognition protein $\mathrm{SC} 2$ (PGRP-SC-2) from nile tilapia Oreochromis 
niloticus involved in the immune response to Streptococcus agalactiae. Fish \& Shelfish Immunology 54: 1-10.

Harborne JB. 2006. Metode Fitokimia. Penerjemah: Patmawinata K dan Soediro I. Edisi Kedua. Bandung. Penerbit ITB.

Hardi EH, Sukenda, Harris E, Lusiastuti AM. 2008. Toxicity of extracellular cell product (ECP) of Streptococcus agalactiae in Nile tilapia Oreochromis niloticus. Jurnal Natur Indonesia 13: 187-199.

Hardi EH, Sukenda, Harris E, Lusiastuti AM. 2011. Characterization and phatogenicity of $\beta$ and non haemolytic Streptococcus agalactiae in cultured Nile tilapia. Jurnal Veteriner 12: 152-164.

Harikrishnan R, Chellam B, Moon-soo H. 2011. Impact of plant product on innate and adaptive immune system of cultured finfish and shellfish. Aquaculture 317: 1-15.

Harikrishnan R, Kim JS, Balasundaram C, Heo MS. 2012. Immunomodulatory effects of chitin and chitosan enriched diets in Epinephelus bruneus against Vibrio alginolyticus infection. Aquaculture 326-329: 46-52.

Hill AF, Polvino WJ, Wilson DB. 2005. The significance of glucose, insulin and potassium for immunology and oncology: a new model of immunity. Journal of Immune Based Therapies and Vaccines 3: 5.

Huang BF, Zou LL, Xie JG, Huang ZC, Li YW, Li Ax. 2013. Immune responses of different species of tilapia infected with Streptococcus agalactiae. Journal of Fish Disease 36: 747-752.

Insana N, Wahyu F. 2015. Substitution of curcuma Xanthorhiza sp. in different doses of feed for growth and survival of tilapia Oreochromis niloticus. Jurnal Ilmu Perikanan 4: 381-391.

Jantrakajorn S, Maisak $\mathrm{H}$, Wongtavatchai J. 2014. Comprehensive investigation of streptococcosis outbreaks in culture nile tilapia Oreochromis niloticus and red tilapia Oreochromis sp., of Thailand. Journal of the world aquaculture society 45: 4 .

Li YW, Huang PR, Fang W, LuoZP, Peng HL, Wang YX, Li XA. 2013. Chronic streptococcosis in Nile tilapia Oreochromis niloticus L., caused by Streptococcus agalactiae. Journal of Fish Diseases 37: 757-763.

Lin LG, Elisaesser CF, Clem LW, Miller NW. 1992. Phorbol ester/calcium ionophore activate fish leukocytes and induce long-term cultures. Developmental and Comparative
Immunology 16: 153-163.

Magnadottir B. 2006. Innate immunity of fish (overview). Fish \& Shellfish Immunology 20: 137-151.

Meena DK, Pronob D, Shailesh K, Mandal SC, Prusty AK, Singh SK, Akhtar MS, Behera BK, Kundar K, Pal AK, Mukherjee SC. 2013. Beta-glucan: an ideal immunostimulant in aquaculture (a review). Fish Physiol Biochem 39: 431-457.

Nugroho RA, Manurung H, Saraswati D, Ladyescha D, Nur FM. 2016. The effects of Terminalia catappa L. leaves extract on the water quality properties, survival and blood profile of ornamental fish Betta sp. cultured. Biosaintifika 8: 241-248.

Onyema CT, Ofor CE, Okudo VC, Ogbuagu AS. 2016. Phytochemical and antimicrobial analysis of banana pseudo stem Musa acuminata. British Journal of Pharmaceutical Research 10: 1-9.

Pandit NP, Nakamura M. 2009. Effect of high temperature on survival, growth, and feed conversion ratio of Nile tilapia, Oreochromis niloticus. Our Nature 8: 219-224.

Pilarski F, Oliveira CAF. Souza FPBD, Zanuzzo FS. 2017. Different $\beta$-glucans improve the growth performance and bacterial resistance in Nile tilapia. Fish \& Shellfish Immunology 70: 25-29.

Poyyamozhi VS, Kadirvel R. 1986. The value of banana stalk as a feed for goats. Animal Feed Science and Technology 15: 95-100.

Queiroz MMF, Marti G, Queiroz EF. 2013. Quantitative determination Tetrapterys mucuronata Alkaloids. Phytochem 1: 1-12.

Rathee P, Chaudhary H, Rathee S, Rathee D, Kumar V, Kohli K. 2009. Mechanism of action of flavonoids as anti-inflamatory agents: a review. Inflammation \& Allergy-Drug Target 8: 229-235.

Rattanavichai W, Chen YN, Chang CC, Cheng W. 2015. The effect of banana Musa acuminata peels hot-water extract on the immunity and resistance of giant freshwater prawn, Macrobrachium rosenbergii via dietary administration for a long term: activity and gene transcription. Fish \& Shellfish Immunology 46: 378-386.

Santangelo K, Vari R, Scazzocchio B, Benedetto R. 2007. Polyphenol, intracelluler signalling and inflamation. Sanita 43: 394-405.

Selim KM, El-hofy H, Khalil RH. 2014. The efficacy of three mycotoxin adsorbents to 
alleviate aflotoxin B-1induced toxicity in Oreochromis niloticus. Aquaculture 22: 523-540.

Selim KM, Rasha MR. 2015. Improvement of immunity and disease resistance in the Nile tilapia Oreochromis niloticus, by dietary supplementation with Bacillus amyloliquefaciens. Fish \& Shellfish Immunology 44: 496-503.

Siregar WS, Nuryati S, Sukenda. 2016. The effectiveness of chopped Kepok banana stem Musa paradisiaca Linn. to prevent motile aeromonad septicaemia disease in catfish Clarias sp.. [unpublish]

Svobodoya Z, Vyukosova B. 1991. Diagnostic, prevention and therapy of fish disease and intoxication. Research Institute of Fish Culture and Hydrobiology Vodnany Czechoslovakia. Pp. 7-23.

Taukhid. 2014. Application of Streptococcus agalactiae vaccine to prevent streptococcosis on tilapia culture, Oreochromis niloticus. Berita Biologi 13.

Wu YR, Gong QF, Fang H, Liang WW, Chen M, He RJ. 2013. Effect of Sophora flavescens on non-spesific immune response of tilapia GIFT Oreochromis niloticus and disease resistance against Streptococcus agalactiae. Fish \& Shellfish Immunology 34: 220-227.

Yi T, Li YW, Liu L, Xiao X, Li AX. 2014. Protection of Nile tilapia Oreochromis niloticus against Streptococcus agalactiae following immunization with recombinant FbsA and $\alpha$-enolase. Aquaculture 428-429: 35-34.

Yunita I, Henni S, Lukistyowati I. 2016. The addition of noni fruit flour Morinda citrifolia to feed on change of phagocytosis activity, total erythrocyte and hemoglobin in tilapia Oreochromis niloticus. Berkala Perikanan Terubuk 44: 38-45. 